\title{
Molecular fingerprinting of Vibrio tapetis strains using three PCR-based methods: ERIC-PCR, REP-PCR and RAPD
}

\author{
José M. Rodríguez ${ }^{1}$, Sonia López-Romalde ${ }^{1,2}{ }^{2}$ Roxana Beaz $^{1}$, M. Carmen Alonso ${ }^{2}$, \\ Dolores Castro ${ }^{2}$, Jesús L. Romalde ${ }^{1, *}$ \\ ${ }^{1}$ Departamento de Microbiología y Parasitología, Facultad de Biología, Universidad de Santiago de Compostela, \\ Campus Sur s/n., 15782 Santiago de Compostela, Spain \\ ${ }^{2}$ Departamento de Microbiología, Facultad de Ciencias, Universidad de Málaga, Campus de Teatinos, 29071 Málaga, Spain
}

\begin{abstract}
Brown Ring Disease (BRD) is a bacterial disease caused by Vibrio tapetis which affects cultured clams and causes heavy economic losses. In this study, $28 \mathrm{~V}$. tapetis strains isolated from 5 different hosts were intraspecifically characterized by 3 different polymerase chain reaction- (PCR-) based typing methods: enterobacteria repetitive intergenic consensus (ERIC)-PCR, repetitive extragenic palindromic (REP)-PCR and randomly amplified polymorphic DNA (RAPD)-PCR. Cluster analysis of genetic profiles obtained from these molecular techniques clearly showed the existence of 3 genetic groups strongly correlated to the host origin. The first group was formed by $23 \mathrm{~V}$. tapetis strains isolated from Manila clam Ruditapes philippinarum, 1 isolated from venus clam Venerupis aurea, and 1 isolated from common cockle Cerastoderma edule, all collected from France and Spain. The second group was formed by 2 strains isolated from carpet-shell clam $R$. decussatus cultured in the northwest of Spain. The third group was composed of 1 strain isolated from Atlantic halibut Hippoglossus hippoglossus from the UK. We concluded that the 3 typing methods based on PCR were useful for the intraspecific typing of $V$. tapetis strains, and that they can potentially be used as a fast and reliable tool for epidemiological studies in the future.
\end{abstract}

KEY WORDS: Vibrio tapetis $\cdot$ RAPD $\cdot$ ERIC-PCR $\cdot$ REP-PCR $\cdot$ Typing

\section{INTRODUCTION}

Brown Ring Disease (BRD), caused by Vibrio tapetis, is a pathology of demonstrated bacterial origin described in adult bivalves cultured in Europe (Paillard et al. 1994, Borrego et al. 1996, Paillard 2004). The main sign characterizing this disease is an organic brown deposit on the inner surface of the shell, typically located between the pallial line and the edge of the shell (Paillard et al. 1994). This disease has been described in 2 different clam species - Manila clam Ruditapes philippinarum and carpet-shell clam $R$. decussatus - in France, England, Ireland, Italy, Spain, and Portugal (Paillard et al. 1994, Figueras et al. 1996,
Allam et al. 2000, Paillard 2004). However, V. tapetis has also been isolated from venus clam Venerupis aurea, common cockle Cerastoderma edule, Atlantic halibut Hippoglossus hippoglossus, and corkwing wrasse Symphodus melops from several European countries (Jensen et al. 2003, Reid et al. 2003).

Previous studies have demonstrated that Vibrio tapetis strains consitute a homogeneous taxon, and share the same biochemical and antigenic properties (Castro et al. 1996, Figueras et al. 1996). However, the use of molecular techniques, including pulsed-field gel electrophoresis (PFGE), ribotyping, plasmid profiling, randomly amplified polymorphic DNA (RAPD) and restriction fragment length polymorphism (RFLP), has 
demonstrated some genetic variations among $V$. tapetis strains (Castro et al. 1997, Romalde et al. 2002, Chevalier et al. 2003).

Repetitive element PCR is a group of techniques that generates DNA fingerprints which can be utilized for the discrimination of bacterial species and/or strains (Versalovic et al. 1991, 1994). These methods involve the application of oligonucleotide primers based on families of short, highly conserved extragenic repetitive sequences, including the repetitive extragenic palindromic (REP) and the enterobacterial repetitive intergenic consensus (ERIC) sequences (Stern et al. 1984, Hulton et al. 1991). REP and ERIC sequences are present in species throughout the Enterobacteriaceae family (Versalovic et al. 1991, Bachellier et al. 1999). The use of appropriate outward-facing PCR primers directed at these repeated sequences generates multiple amplification products, which reflect distance polymorphisms between adjacent DNA repeats. PCR with primers based on ERIC and REP sequences has been successfully used to differentiate bacterial strains from diverse species (de Bruijn 1992, Bennasar et al. 2002, Bruant et al. 2003, Hahm et al. 2003).

The RAPD assay is based on the use of short random sequence primers, 9 to 10 bases in length, which hybridize with sufficient affinity to chromosomal DNA sequences to render a pattern of bands that is used for fingerprinting bacterial strains (Welsh \& McClelland 1990, Williams et al. 1990). A number of studies have reported success in using RAPD assays to distinguish bacterial strains in diverse species (Aznar et al. 1993, Inglis et al. 1996, Magariños et al. 2000, O'Hici et al. 2000).

In this study, these 3 PCR-based methods were employed to analyse the intraspecific genetic variability within Vibrio tapetis strains. In addition, their usefulness as epidemiological tools for this shellfish pathogen was evaluated.

\section{MATERIALS AND METHODS}

Bacterial strains and DNA extraction. A total of 28 strains of Vibrio tapetis were used in this study. The geographic origin of these strains as well as the host and year of isolation are listed in Table 1. The characteristics of the strains have been described elsewhere (Borrego et al. 1996, Castro et al. 1996). Confirmatory identification of the isolates was performed by a PCR protocol developed in our labora- tory using the specific primers Jvt-1 and Jvt-2 (Rodríguez et al. 2003), which amplify an internal region of $816 \mathrm{bp}$ in the $16 \mathrm{~S}$ rRNA gene. All strains were routinely grown aerobically on Marine Agar (Pronadisa) at $22^{\circ} \mathrm{C}$ for $48 \mathrm{~h}$. Stock cultures were maintained frozen at $-80^{\circ} \mathrm{C}$ in Marine Broth (Oxoid) supplemented with $15 \%$ (v/v) glycerol.

Chromosomal DNA was extracted using the InstaGene Matrix (Bio-Rad) as previously described (Romalde et al. 2002), which in all cases rendered a concentration ranging between 3.4 and $3.7 \mu \mathrm{g} \mu \mathrm{l}^{-1}$. Extracted DNA was maintained at $-20^{\circ} \mathrm{C}$ until used for PCR reactions.

PCR primers and amplification conditions. ERICPCR and REP-PCR were carried out with Ready-to-go PCR beads (Amersham Pharmacia Biotech). These commercial beads have been optimized for $\mathrm{PCR}$ reactions and contain buffer, nucleotides, and Taq DNA polymerase; therefore, the only reagents added to the reaction were template DNA $(1 \mu \mathrm{l})$, primers $(100 \mathrm{pmol}$ each), and water to complete a volume of $25 \mu \mathrm{l}$. The ERIC and REP primers used in this study were described in detail previously (Versalovic et al. 1994), and are listed in Table 2.

The RAPD reactions were performed using ReadyTo-Go RAPD analysis beads (Amersham Pharmacia Biotech), optimized for RAPD-PCR reactions and, as with PCR beads (see paragraph above), containing buffer, nucleotides, and Taq DNA polymerase.

Table 1. Vibrio tapetis. Strains included in this study. Virulence for clam: data obtained from our laboratory and from Castro (1994), Maes (1992) and Novoa et al. (1998). Hosts are from cultured stocks unless otherwise noted

\begin{tabular}{|c|c|c|c|}
\hline Strain & Host & Strains & Virulence \\
\hline \multicolumn{4}{|c|}{ Landeda, France } \\
\hline 1988 & Ruditapes philippinarum & IS1 & + \\
\hline 1990 & R. philippinarum & B1090 & + \\
\hline 1991 & R. philippinarum & IS5, B2.1, B8.1, B9.3, B11.1 & + \\
\hline 1991 & R. philippinarum & $\begin{array}{l}\text { B2.3, B8.3, B8.4, B8.5, B8.6, } \\
\text { B8.7, B8.17, B8.19, B9.4, } \\
\text { B9.5, B9.7, B11.2, B11.4 }\end{array}$ & ND \\
\hline \multicolumn{4}{|c|}{ Quiberon, France } \\
\hline 1990 & R. philippinarum & IS7 & + \\
\hline 1990 & Venerupis aurea $^{\mathrm{b}}$ & IS8 & + \\
\hline 1990 & Cerastoderma edule ${ }^{\mathrm{b}}$ & IS9 & + \\
\hline \multicolumn{4}{|c|}{ Galicia, Spain } \\
\hline 1994 & R. philippinarum & 1703RP, 6301RP & + \\
\hline 1994 & R. decussatus & 0202RD, 0705RD & + \\
\hline 2005 & R. philippinarum & CMJ 10.7, C11.25 & + \\
\hline \multicolumn{4}{|c|}{ Scotland, UK } \\
\hline 2001 & Hippoglossus hippoglossus & 6087 & ND \\
\hline \multicolumn{4}{|c|}{$\begin{array}{l}{ }^{a} \text { Type strain (Spanish Type Culture Collection Code: } \\
\text { CECT } 4600^{\mathrm{T}} \text { ) }\end{array}$} \\
\hline
\end{tabular}


Reagents which must be added to the reaction are template DNA $(1 \mu \mathrm{l})$ and $25 \mathrm{pmol}$ of respective RAPD primers (which are also provided in the kit) to make a $25 \mathrm{\mu l}$ total volume. The oligonucleotide sequence of the 10-mer primers used are listed in Table 2.

All PCR amplifications were carried out in a T-Gradient thermocycler (Biometra). The amplification protocols employed were: for ERIC-PCR 1 cycle of $95^{\circ} \mathrm{C}$ for $5 \mathrm{~min}, 35$ cycles of $92^{\circ} \mathrm{C}$ for $45 \mathrm{~s}, 52^{\circ} \mathrm{C}$ for $1 \mathrm{~min}$, and $70^{\circ} \mathrm{C}$ for $10 \mathrm{~min}$, with a final extension step of $70^{\circ} \mathrm{C}$ for $10 \mathrm{~min}$; for REP-PCR 1 cycle of $95^{\circ} \mathrm{C}$ for $7 \mathrm{~min}$, 35 cycles of $92^{\circ} \mathrm{C}$ for $45 \mathrm{~s}, 40^{\circ} \mathrm{C}$ for $1 \mathrm{~min}$, and $72^{\circ} \mathrm{C}$ for $8 \mathrm{~min}$, with a final extension of $72^{\circ} \mathrm{C}$ for $15 \mathrm{~min}$; and for RAPD amplifications 1 cycle of $95^{\circ} \mathrm{C}$ for $1 \mathrm{~min}$, 30 cycles of $95^{\circ} \mathrm{C}$ for $1 \mathrm{~min}, 35^{\circ} \mathrm{C}$ for $1 \mathrm{~min}$, and $72^{\circ} \mathrm{C}$ for $2 \mathrm{~min}$, with a final step of $72^{\circ} \mathrm{C}$ for $5 \mathrm{~min}$.

In addition, in order to determine whether the ERIC and REP sequences were actually present in the genome of Vibrio tapetis or if the PCR amplicons obtained were random products due to non-specific amplifications, DNA extracted from strains $V$. tapetis

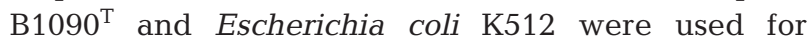
annealing temperature gradient assays of ERIC-PCR and REP-PCR. The annealing temperatures ranged from 52 to $66^{\circ} \mathrm{C}$ for ERIC-PCR and from 40 to $64^{\circ} \mathrm{C}$ for REP-PCR.

In all cases, amplification products were analyzed by horizontal $1 \%$ (wt/vol) agarose gels with TAE (0.04 M Tris-acetate, 1 mM EDTA) electrophoresis buffer. After staining with ethidium bromide, gels were photographed under UV light. A 50-2000 bp ladder (Sigma Chemical) was included as molecular weight marker.

In order to determine significant differences in the patterns, reproducibility of results were assessed by repetition in at least 3 independent ERIC, REP and RAPD assays.

Computer data analysis. All gels were scanned and images were captured by a Gel Doc-2000 gel documentation system (Bio-Rad). For the analysis and com-

Table 2. ERIC, REP and RAPD primers used in this study. A: adenine, T: thymine, G: guanine, C: cytosine, M: adenine or cytosine, R: adenine or guanine, $\mathrm{Y}$ : cytosine or thymine, $\mathrm{N}$ : any nucleotide; $T_{\mathrm{m}}$ : maximum temperature

\begin{tabular}{|lclc|}
\hline Method & Primer & Sequence & $T_{\mathrm{m}}\left({ }^{\circ} \mathrm{C}\right)$ \\
\hline ERIC-PCR & ERIC1R & 5' ATGTAAGCTCCTGGGGATTCAC 3' & 65.1 \\
& ERIC2 & 5' AAGTAAGTGACTGGGGTGAGCG 3' & 66.4 \\
REP-PCR & REP1D & 5' NNNRCGYCGNCATCMGGC 3' & 62.5 \\
& REP2D & 5' RCGYCTTATCMGGCCTAC 3' & 55.1 \\
RAPD-PCR & P2 & 5' GTTTCGCTCC 3' & \\
& P4 & 5' AAGAGCCCGT 3' & \\
& P5 & 5' AACGCGCAAC 3' & \\
\hline
\end{tabular}

parison of patterns, data analysis was performed by using the Diversity Database software (Bio-Rad). The computed similarities among isolates were estimated by means of the Dice coefficient (Dice 1945). Dendrograms were produced using the unweighted pair group method average (UPGMA).

\section{RESULTS}

The PCR analysis allowed confirmation of the 28 isolates studied as Vibrio tapetis strains, and produced a single product with the expected $816 \mathrm{bp}$ length in all strains examined (data not shown). All the $V$. tapetis strains included in the study were typeable: none of them failed to yield discernible amplification patterns by any of the PCR-based methods analyzed.

Three different genetic profiles were obtained using ERIC-PCR, placing the tested strains in 3 different groups (Fig. 1). Genetic Profile I showed 12 bands with sizes between $147 \mathrm{bp}$ and $3082 \mathrm{bp}$, Profile II had 8 bands ranging from 147 to $1560 \mathrm{bp}$, and Profile III presented 9 bands whose molecular weights ranged between 138 and $2523 \mathrm{bp}$. The first group was formed by 23 Vibrio tapetis strains isolated from Manila clam and 1 each isolated from the venus clam and common cockle, most of which were isolated in France. The second group contained 2 strains isolated from carpetshell clam collected in the Northwest of Spain. The third group was composed of only 1 strain isolated from Atlantic halibut in the UK.

In the case of the REP-PCR the results were similar. The profiles obtained placed the strains tested in 3 differentiated groups (Fig. 2), made up of the same strains as in the previous case (Fig. 1). Profiles A and $C$ had 9 bands each ranging from 85 to $2743 \mathrm{bp}$, while Profile B had only 3 bands that were shared with the other 2 patterns and whose molecular weights were between 744 and 1977 bp. The groups were also highly homogenous. A difference of 2 bands was only observed in Profile A for the type strain B1090 ${ }^{\mathrm{T}}$, which lacked the band of smaller molecular weight (189 bp) and yet had a larger band (295 bp) not present in other strains of this group.

In the case of the RAPD technique, we only used primers P2, P4 and P5 because previous studies demonstrated that using only these 3 primers generated an appropriate pattern of amplified products suitable for accurate analysis (Romalde et al. 2002). On the basis of RAPD genetic profiles, considered as either originating from only 1 primer or as a combination of the 3 band patterns, the strains of Vibrio 

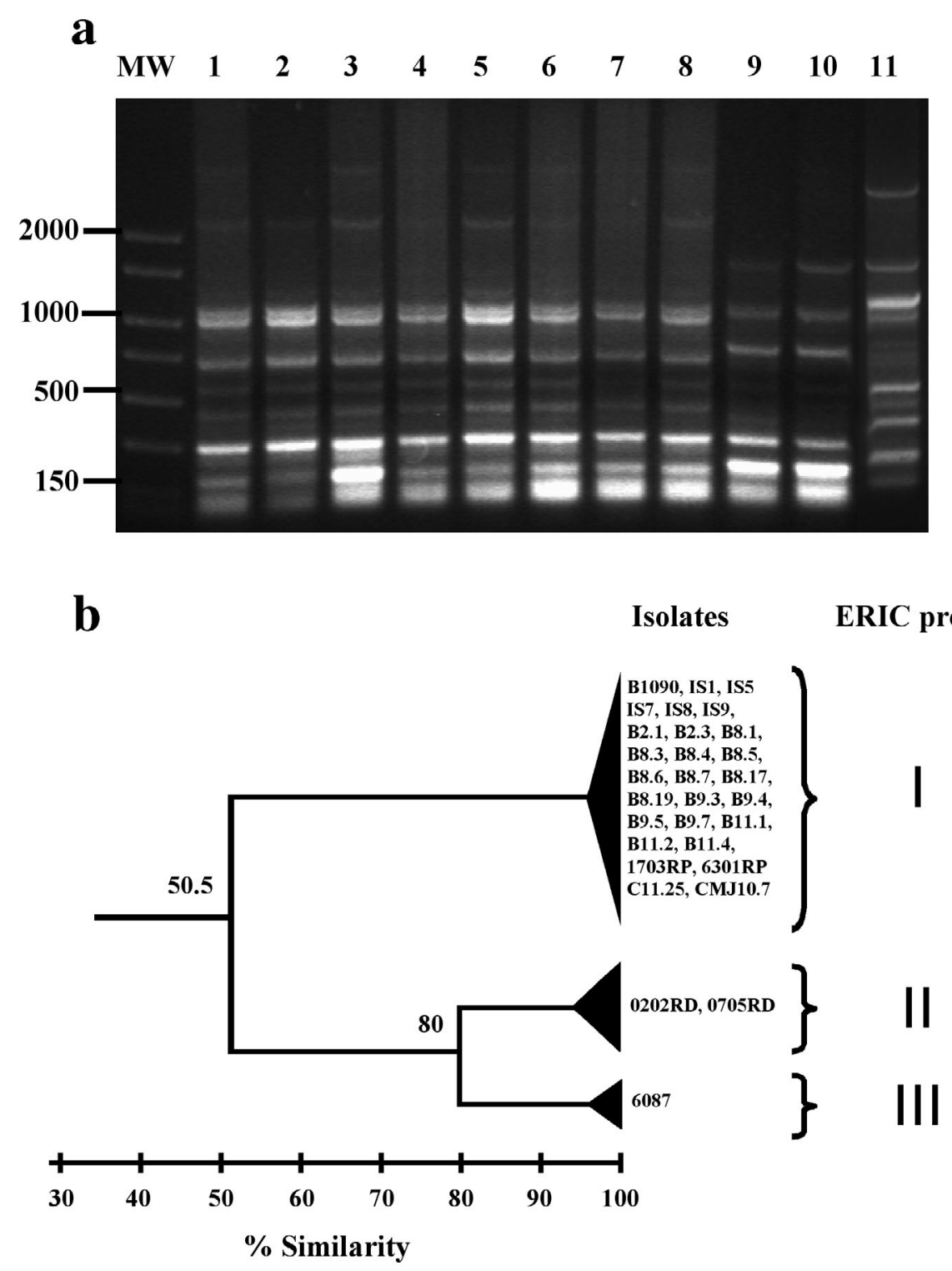

Fig. 1. Vibrio tapetis. (a) Enterobacterial repetitive intergenic consensus PCR (ERIC-PCR) patterns of strains. Lanes 1: B1090 ; 2: IS8; 3: IS9; 4: B8.3; 5: B9.4; 6: B8.7; 7: 1703RP; 8: 6301RP; 9: 0705RD; 10: 0202RD; 11: 6087. Molecular weight (MW): 50 to 2000 bp ladder. Numbers on left: position of molecular size markers in bp. (b) Dendrogram obtained using Dice similarity coefficient and unweighted pair group method average (UPGMA) analysis on the basis of ERIC profiles. Numbers along branches: \% similarity

tapetis were clustered in 3 genetic groups (Fig. 3) comprising the same strains as in the previous cases.

Reproducibility of ERIC-PCR, REP-PCR and RAPDPCR results was assessed by repetition in at least 3 independent assays. Excluding some variations in band intensity, no differences were observed among the profiles obtained for each strain, and all band patterns proved to be highly reproducible.

DNA from Escherichia coli K512 and Vibrio tapetis $\mathrm{B} 1090^{\mathrm{T}}$ were subjected to ERIC-PCR and REPPCR using a gradient of annealing temperatures. As the annealing temperature was progressively increased, a failure in the amplification of the greatest molecular weight bands was observed for both bacterial species (Fig. 4). Nevertheless, amplification bands lower than 1000 bp never disappeared completely at annealing temperatures close to the maximum temperature $\left(T_{\mathrm{m}}\right)$ of the ERIC and REP primers.

\section{DISCUSSION}

For epizootiological purposes, the intraspecific typing of Vibrio tapetis is of great value for the recognition 

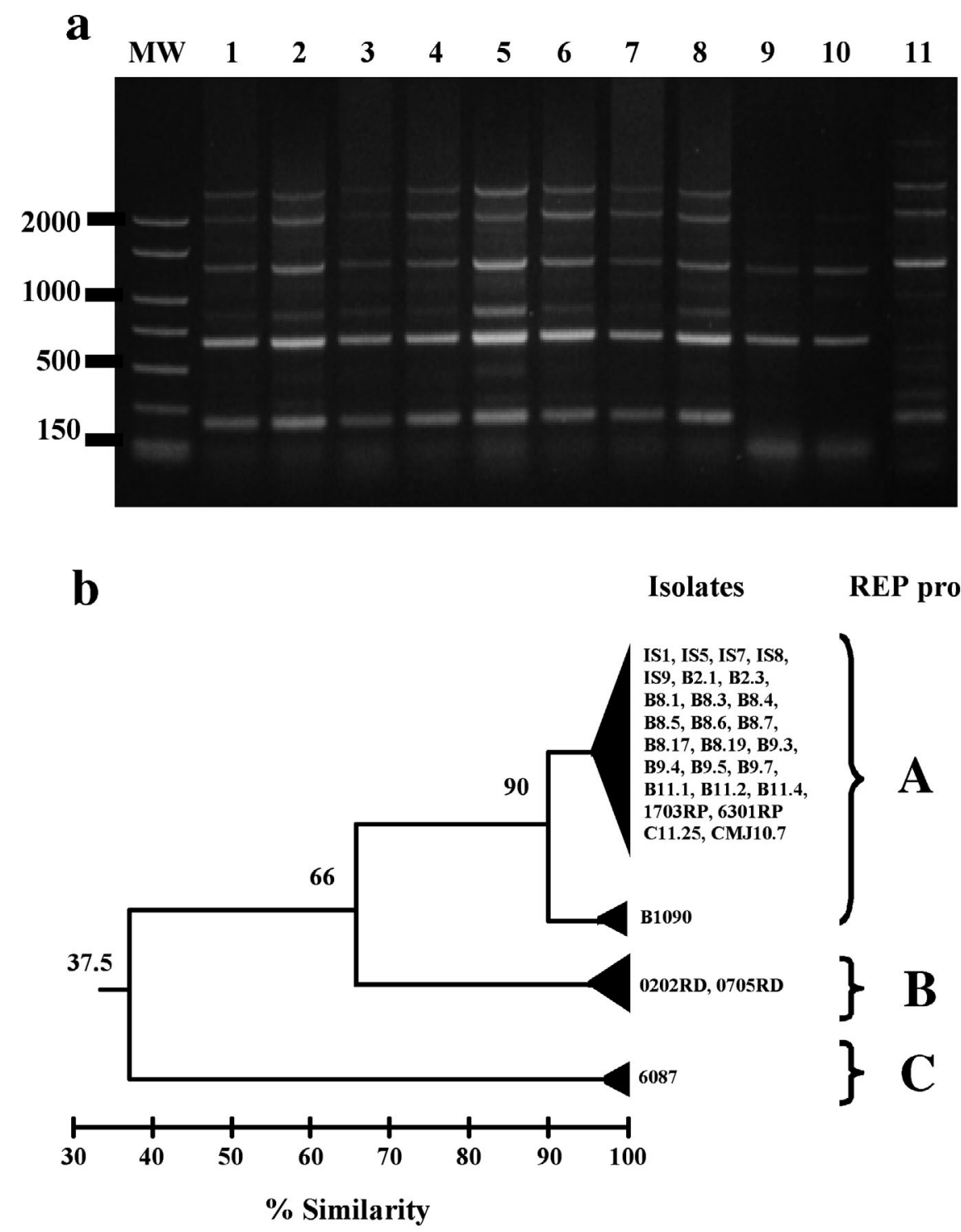

Fig. 2. Vibrio tapetis. (a) Repetitive extragenic palindromic PCR (REP-PCR) patterns of strains. Lanes $1:$ B1090 ${ }^{\mathrm{T}} ; 2$ : IS8; $3:$ IS9; 4 : B8.3; 5: B9.4; 6: B8.7; 7: 1703RP; 8: 6301RP; 9: 0705RD; 10: 0202RD; 11: 6087. MW: 50 to 2000 bp ladder. Numbers on left: position of molecular size markers in bp. (b) Dendrogram obtained using Dice similarity coefficient and UPGMA analysis on the basis of REP profiles. Numbers along branches: \% similarity

of disease outbreaks, the detection of particularly virulent strains, and the study of the geographical and host distribution of possible variants of this shellfish pathogen (Romalde et al. 2002). Intraspecific discrimination using traditional typing methods, such as biotyping, serotyping or plasmid content, have been shown to have little use for the study of this shellfish pathogen (Borrego et al. 1996, Castro et al. 1996). PCRbased typing methods are being adopted quickly because they are fast, not complex, have discriminatory capabilities, and are of low cost. For these reasons, in this study we evaluated the use of 3 PCR-based methods for typing $V$. tapetis strains.
Rivera et al. (1995a) proposed the use of ERIC-PCR for typing diverse Vibrio species, including $V$. mimicus, V. vulnificus, V. parahaemolyticus, V. campbelli, V. mediterranei, and $V$. alginolyticus. This technique and REP-PCR have been sucessfully used in the discrimination of strains of $V$. cholerae (Rivera et al. 1995b), $V$. halioticoli (Sawabe et al. 2002), and V. parahaemolyticus (Wong \& Lin 2001, Khan et al. 2002). On the other hand, the RAPD assay has proved to be an appropriate method for typing and epidemiological studies of different micro-organisms, including bacteria and yeasts (Aznar et al. 1993, Inglis et al. 1996, Magariños et al. 2000, O'Hici et al. 2000). 

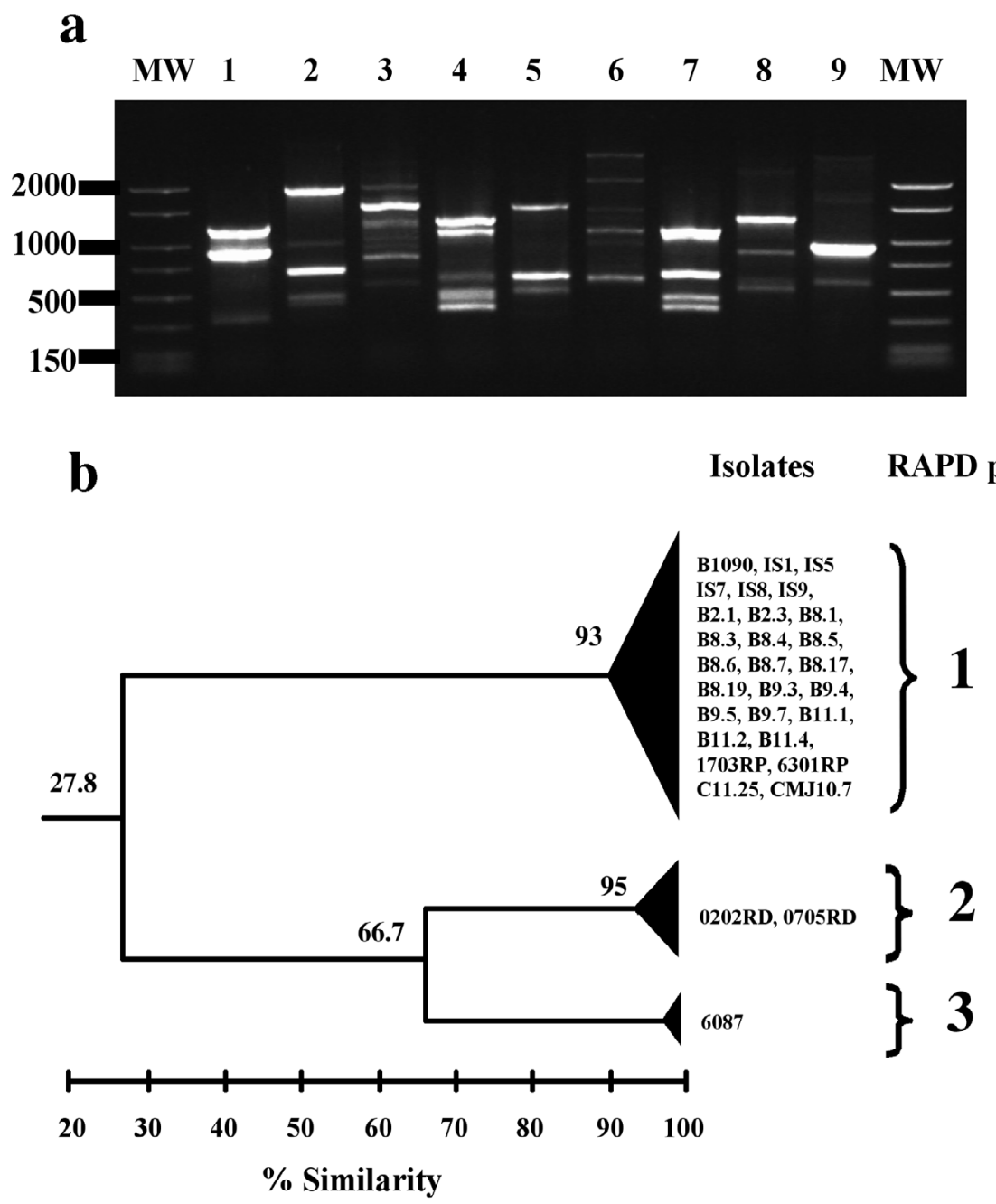

Fig. 3. Vibrio tapetis. (a) Randomly amplified polymorphic DNA (RAPD)-PCR patterns of strains using primers P2, P4 and P5. Lanes 1 to 3: B1090 ${ }^{\mathrm{T}}$ amplified with primer P2, P4 and P5, respectively; 4 to 6: 0202RD amplified with primer P2, P4 and P5, respectively; 7 to 9: 6087 amplified obtained with primer P2, P4 and P5, respectively. MW: 50 to 2000 bp ladder. Numbers on left: position of molecular size markers in bp. (b) Dendrogram obtained using Dice similarity coefficient and UPGMA analysis on the basis of RAPD profiles. Numbers along branches: \% similarity

The results obtained in this study clearly demonstrated the existence of 3 genetic groups strongly correlated with the origin of the host. The first cluster included all strains isolated from Ruditapes philippinarum, the second cluster included all strains isolated from $R$. decussatus, and the third only 1 strain isolated from Hippoglossus hippoglossus. In addition, our results clearly showed that the groups were very homogenous: no significant differences were observed among profiles of strains belonging to a same group Intraspecific variability has been observed within many species of the genus Vibrio, including some pathogenic for marine organisms such as $V$. anguillarum, $V$. vulnificus, and V. halioticoli (Aznar et al. 1993, Toranzo et al. 1997, Sawabe et al. 2002). In V. anguillarum (now
Listonella anguillarum), 2 clonal lineages were observed within the serotypes $\mathrm{O} 1$ and $\mathrm{O} 2$ of this microorganism that were related to genetic differences between north and south European isolates. For $V$. vulnificus, genetic techniques such as RAPD and amplified fragment length polymorphism (AFLP) have been described as powerful tools to discriminate eel-pathogenic strains from clinical and environmental isolates. In the case of environmental Vibrio spp., an even greater diversity of strains has been described (Wong \& Li 2001, Maluping et al. 2005).

To our knowledge, although some of the French isolates can be related epidemiologically (corresponding to 4 samplings conducted in the same bay and season), no evidence of linkage exists between French and 

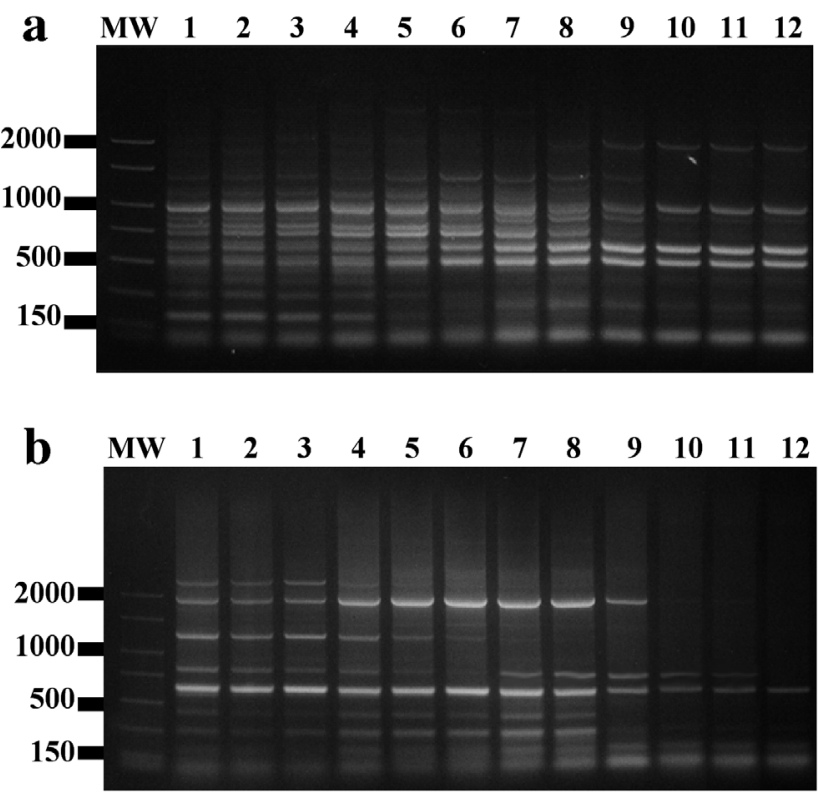

Fig. 4. REP-PCR profiles obtained for (a) Escherichia coli K512 and (b) Vibrio tapetis $\mathrm{B} 1090^{\mathrm{T}}$ using a gradient of annealing temperatures. Lanes 1 to 12 annealing temperatures $\left({ }^{\circ} \mathrm{C}\right)-1: 40$, 2: 40.5; 3: 42.2; 4: 44.8; 5: 47.7; 6: 50.5; 7: 53.4; 8: 56.2; 9: 59.1; 10: $61.7 ; 11: 63.4 ; 12: 64$. MW: 50 to 2000 bp ladder. Numbers on left: position of molecular size markers in bp

Spanish Manila clam stocks or within Spanish isolates from Ruditapes decussatus and $R$. phillipinarum. In addition, bearing in mind the data available on the virulence of the isolates, no correlation could be found between this characteristic and membership to a specific genogroup. On the other hand, IS8 and IS9 strains were isolated from natural populations of venus clam and common cockle in France. These populations were near populations of Manila clams affected by BRD. This, together with the fact that Vibrio tapetis is an opportunistic pathogen, can explain why these 2 strains had the same genetic profile as those isolated from Manila clams. These results are in full agreement with those of other studies that used different molecular typing methods (Castro et al. 1997, Romalde et al. 2002, Chevalier et al. 2003).

Gillings \& Holley (1997a) examined the use of ERICPCR in several bacteria, bacteriophages, invertebrates, fungi, plants and vertebrates, and demonstrated that complex ERIC-PCR patterns can be readily produced from all of these target organisms. Nevertheless, sequences similar to ERIC have not been detected in bacteriophages or in eukaryotes. The ERIC and REP sequences have only been confirmed in members of the Enterobacteriaceae family and in Vibrio cholerae (Bachellier et al. 1999); the ERIC sequence of $V$. cholerae, located near the haemolysin gene, is highly homologous with those found in Enterobacteriaceae species. A previous study speculated that a transpecific genetic exchange had affected a group of Escherichia coli haemolysin genes, and that the ERIC sequence 'hitchhiked' with the haemolysin gene (Hulton et al. 1991).

Gillings \& Holley (1997b) confirmed that ERIC-PCR fingerprints had sometimes been formed by random amplification. In such cases, ERIC primers were actually annealing to, and amplifying from, anonymous binding sites with accidental and only partial homology to primer sequences; this was due to differences between the commonly used annealing temperature for REP-PCR and the $T_{\mathrm{m}}$ of ERIC and REP primers (Gillings \& Holley 1997b). This conclusion does not imply, however, that ERIC- or REP-PCR may be useless for typing micro-organisms. In fact, ERIC- and REPPCR have been described as highly reproducible and sensitive, and have been widely used for this aim with successful results (Rivera et al. 1995a,b, Wong \& Lin 2001, Khan et al. 2002, Sawabe et al. 2002). For Vibrio tapetis, although a decrease in the number of bands was observed, ERIC- and REP-PCR profiles were achieved even when the annealing temperature was raised near the respective primer $T_{\mathrm{m}}$. Similar results were observed in Escherichia coli, which is in agreement with other studies (Gillings \& Holley 1997b). These facts indicated the presence of these repetitive consensus sequences (ERIC and REP) in $V$. tapetis.

In summary, in this study we reported the close association between host and strain of Vibrio tapetis, and demonstrated the utility of 3 PCR-based methods (ERIC, REP and RAPD) for epidemiological studies of this shellfish pathogen.

Acknowledgements. This research was supported in part by Grant AGL2003-09307-C02-00 from the Ministerio de Ciencia y Tecnología (Spain). R.B. thanks the Ministerio de Educación y Ciencia (Spain) for a research fellowship. We gratefully acknowledge the donors for the kind supply of some strains.

\section{LITERATURE CITED}

Allam B, Paillard C, Howard A, Le Pennec M (2000) Isolation of the pathogen Vibrio tapetis and defense parameters in brown ring diseased Manila clams Ruditapes philippinarum cultivated in England. Dis Aquat Org 41:105-113

Aznar R, Ludwing W, Schleifer KH (1993) Ribotyping and randomly amplified polymorphic DNA analysis of Vibrio vulnificus biotypes. Syst Appl Microbiol 16:303-309

Bachellier S, Clément JM, Hofnung M (1999) Short palindromic repetitive DNA elements in enterobacteria: a survey. Res Microbiol 150:627-639

Bennasar A, Luna G, Cabrer B, Lalucat J (2002) Rapid identification of Salmonella typhmurium, $S$. enteritidis and $S$. virchow isolates by polymerase chain reaction based 
fingerprinting methods. Int Microbiol 3:31-38

Borrego JJ, Castro D, Luque A, Paillard C, Maes P, Garcia MT, Ventosa A (1996) Vibrio tapetis sp. nov., the causative agent of the brown ring disease affecting cultured clams. Int J Syst Bacteriol 46:480-484

Bruant G, Watt S, Quentin R, Rosenau A (2003) Typing of nonencapsulated Haemophilus strains by repetitive-element sequence-based PCR using intergenic dyad sequence. J Clin Microbiol 41:3473-3480

Castro D (1994) Patologías de origen bacteriano en almejas cultivadas Tapes decussatus y $T$. philippinarum. $\mathrm{PhD}$ thesis, University of Málaga

Castro D, Santamaria JA, Luque A, Martinez-Manzanares E, Borrego JJ (1996) Antigenic characterization of the etiological agent of the brown ring disease affecting Manila clams. Syst Appl Microbiol 19:231-239

Castro D, Romalde JL, Vila J, Magariños B, Luque A, Borrego JJ (1997) Intraspecific characterization of Vibrio tapetis strains by use of pulsed-field gel electrophoresis, ribotyping and plasmid profiling. Appl Environ Microbiol 63: 1449-1452

Chevalier P, Boula C, Paillard C (2003) Characterization by restriction fragment length polymorphism and plasmid profiling of Vibrio tapetis strains. J Basic Microbiol 5: 414-422

de Bruijn FJ (1992) Use of repetitive (repetitive extragenic palindromic and enterobacterial repetitive intergenic consensus) sequences and polymerase chain reaction to fingerprint the genomes of Rhizobium meliloti isolates and other soil bacteria. Appl Environ Microbiol 58:2180-2187

Dice LR (1945) Measures of the amount of ecological association between species. Ecology 26:297-302

Figueras A, Robledo JAF, Novoa B (1996) Brown ring disease and parasites in clams (Ruditapes decussatus and R. philippinarum) from Spain and Portugal. J Shellfish Res 15: 363-368

Gillings M, Holley M (1997a) Amplification of anonymous DNA fragments using pairs of long primers generates reproducible DNA fingerprints that are sensitive to genetic variation. Electrophoresis 18:1512-1518

Gillings M, Holley M (1997b) Repetitive element PCR fingerprinting (REP-PCR) using enterobacterial repetitive intergenic consensus (ERIC) primers is not necessarily directed at ERIC elements. Lett Appl Microbiol 25:17-21

Hahm BK, Maldonado Y, Schreiber E, Bhunia AK, Nakatsu CH (2003) Subtyping of foodborne and environmental isolates of Escherichia coli by multiplex-PCR, Rep-PCR, PFGE, ribotyping and AFLP. J Microbiol Methods 53:387-399

Hulton CSJ, Higgins CF, Sharp PM (1991) ERIC sequences: a novel family of repetitive elements in the genomes of Escherichia coli, Salmonella typhimurium and other enterobacteria. Mol Microbiol 5:825-834

Inglis V, Colquhoun D, Pearson MD, Miyata M, Aoki T (1996) Analysis of DNA relationships among Aeromonas species by RAPD (randomly amplified polymorphic DNA) typing. Aquac Int 4:43-53

Jensen S, Samuelsen OB, Andersen K, Torkildsen L, Lambert C, Choquet G, Paillard C, Bergh O (2003) Characterization of strains of Vibrio splendidus and V. tapetis isolated from corkwing wrasse Symphodus melops suffering vibriosis. Dis Aquat Org 53:25-31

Khan A, McCarthy S, Wang RF, Cerniglia CE (2002) Characterization of United States outbreak isolates of Vibrio parahaemolyticus using enterobacterial repetitive intergenic consensus (ERIC) PCR and development of a rapid PCR method for detection of O3:K6 isolates. FEMS Microbiol Lett 206:209-214
Maes P (1992) Pathologie bactérienne chez deux invertébrés matins. La maladie des lésions vertes chez les échinides réguliers et la maladie de l'anneu brun de la palourde: Ruditapes philippinarum. $\mathrm{PhD}$ thesis, University of Bretagne Occidentale, Brest

Magariños B, Toranzo AE, Barja JL, Romalde JL (2000) Existence of two geographically-linked clonal lineages in the bacterial fish pathogen Photobacterium damselae subsp. piscicida evidenced by random amplified polymorphic DNA analysis. Epidemiol Infect 125:213-219

Maluping R, Ravelo C, Lavilla-Pitogo C, Krovacek K, Romalde JL (2005) Molecular typing of Vibrio parahaemolyticus strains isolated from the Philippines by PCR-based methods. J Appl Microbiol 99:383-391

Novoa B, Luque A, Castro D, Borrego JJ, Figueras A (1998) Characterization and infectivity of four bacterial strains isolated from brown ring disease-affected clams. J Invertebr Pathol 71:34-41

O'Hici B, Olivier G, Power R (2000) Genetic diversity of the fish pathogen Aeromonas salmonicida demonstrated by random amplified polymorphic DNA and pulsed-field gel electrophoresis. Dis Aquat Org 39:109-119

Paillard C (2004) A short-review of brown ring disease, a vibriosis affecting clams, Ruditapes philippinarum and Ruditapes decussatus. Aquat Living Resour 17:467-475

Paillard C, Maes P, Oubella R (1994) Brown ring disease in clams. Annu Rev Fish Dis 4:219-240

Reid HI, Duncan HL, Laidler A, Hunter D, Birkbeck TH (2003) Isolation of Vibrio tapetis from cultivated Atlantic halibut (Hippoglossus hippoglossus L.). Aquaculture 221:65-74

Rivera IG, Chowdhury MAR, Huq A, Colwell RR, Martins MT (1995a) Genomic fingerprinting of Vibrio species using ERIC primers and PCR, abstract R-10. In: Abstracts of the 95th General Meeting of the American Society for Microbiology. American Society for Microbiology, Washington, DC, $\mathrm{p} \mathrm{R}-10$

Rivera IG, Chowdhury MAR, Huq A, Jacobs D, Martins MT, Colwell RR (1995b) Enterobacterial repetitive intergenic consensus sequences and the PCR to generate fingerprints of genomic DNAs from Vibrio cholerae O1, O139 and non-O1 strains. Appl Environ Microbiol 61:2898-2904

Rodríguez JM, Toranzo AE, Romalde JL (2003) Development and optimization of a new PCR-based protocol for rapid diagnosis of Vibrio tapetis, the causative agent of the brown ring disease in clams. In: Abstracts of the 11th International Conference of the European Association of Fish Pathologists, St. Juliens, p P-113

Romalde JL, Castro D, Magariños B, Lopez-Cortes L, Borrego JJ (2002) Comparison of ribotyping, randomly amplified polymorphic DNA and pulsed-field gel electrophoresis for molecular typing of Vibrio tapetis. Syst Appl Microbiol 25:544-550

Sawabe T, Thompson FL, Heyrman J, Cnockaert M and 10 others (2002) Fluorescent amplified fragment length polymorphism and repetitive extragenic palindrome-PCR fingerprinting reveal host-specific genetic diversity of Vibrio halioticoli-like strains isolated from the gut of Japanese abalone. Appl Environ Microbiol 68:4140-4144

Stern MJ, Ames GFL, Smith NH, Robinson EC, Higgins CF (1984) Repetitive extragenic palindromic sequences: a mayor component of the bacterial genome. Cell 37: 1015-1026

Toranzo AE, Santos Y, Barja JL (1997) Immunization with bacterial antigens: Vibrio infections. In: Gudding R, Lillehaug A, Midtlyng PJ, Brown F (eds) Fish Vaccinology. Karger, Basel, p 93-105 
Versalovic J, Koeuth T, Lupski JR (1991) Distribution of repetitive DNA sequences in eubacteria and application to fingerprinting of bacterial genomes. Nucleic Acids Res 19: 6823-6831

Versalovic J, Schneider M, de Bruijn FJ, Lupski JR (1994) Genomic fingerprinting of bacteria using repetitive sequence-based polymerase chain reaction. Methods Mol Cell Biol 5:25-40

Welsh J, McClelland, M (1990) Fingerprinting genomes using

Editorial responsibility: Carey Cunningham, Aberdeen, UK
PCR with arbitrary primers. Nucleic Acids Res 18: 7213-7218

Williams JGK, Kubelik AR, Livak KJ, Rafalski JA, Tingey SV (1990) DNA polymorphisms amplified by arbitrary primers are useful as genetic markers. Nucleic Acids Res 18: 6351-6357

Wong H, Lin C (2001) Evaluation of typing of Vibrio parahaemolyticus by three PCR methods using specific primers. J Clin Microbiol 39:4233-4240

Submitted: May 17, 2005; Accepted: November 8, 2005 Proofs received from author(s): March 2, 2006 